This item was submitted to Loughborough's Research Repository by the author.

Items in Figshare are protected by copyright, with all rights reserved, unless otherwise indicated.

\title{
Assessing the sociology of sport: on globalization and the diffusion of sport
}

PLEASE CITE THE PUBLISHED VERSION

http://dx.doi.org/10.1177/1012690214547374

PUBLISHER

SAGE Publications / @ The Author

VERSION

AM (Accepted Manuscript)

PUBLISHER STATEMENT

This work is made available according to the conditions of the Creative Commons Attribution-NonCommercialNoDerivatives 4.0 International (CC BY-NC-ND 4.0) licence. Full details of this licence are available at: https://creativecommons.org/licenses/by-nc-nd/4.0/

\section{LICENCE}

CC BY-NC-ND 4.0

\section{REPOSITORY RECORD}

Maguire, Joseph. 2019. "Assessing the Sociology of Sport: On Globalization and the Diffusion of Sport". figshare. https://hdl.handle.net/2134/21156. 


\section{Assessing the Sociology of Sport: Globalization and the Diffusion of Sport}

The link between sport and global processes is now taken for granted. It is a 'known known'. We are also able to grasp, given our current state of knowledge, that there are 'known unknowns.' However, in the development of knowledge regarding sport and globalization, there have been many 'unknown unknowns' (Taleb, 2007). As with sociological enquiry more generally, in order to understand such dynamics we need to place ourselves in a position of 'not knowing'. Our stock of social scientific knowledge has expanded considerably over the past fifty years - but, with hindsight, we can assume too much, and sometimes, we forget too much, about past work. Knowledge can expand and contract. Our contemporary knowledge concerning sport and globalization rests on a range of scientific establishments, orthodoxies and hegemonic theories, but we must remain open to the unanticipated and, even, the improbable.

The first systematic linkage between the diffusion and contemporary character of sport and the concept of globalization began to appear in the late 1980s and early 1990s, for which the International Review for the Sociology of Sport (IRSS) played an important role. If we survey the past fifty years it is clear that the sociogenesis of some of this research lies deep in the roots of the journal and ICSS/ISSA conferences: both provided a forum for 'cutting edge' theoretical/empirical development and provided non-Western scholars a forum for engagement. 'Cross Cultural Research on Sport' was the theme for both the First International Workshop of ICSS, held in 1967 in Urbana, USA, and a second workshop, held the year after in Leicester, UK. For this period, and the 1970s, IRSS contains much of this cross-cultural research. For my part, two scholars of this period stand out. Kalevi Heinilä, a founding member of ICSS in 1965, explored the issue of the totalization of international sport (Heinilä, 1982). This work still has much to say about the contemporary character and trajectory of global sport. In addition, Norbert Elias (1986: 43-44) observed that achievement 
sport had become 'dominated and patterned by global tensions and rivalries between different states'.

Drawing on this work and that of others, my first published research in this area appeared in IRSS examining the Americanization of English basketball (Maguire, 1988), In the same year, at an ICSS conference in Israel, I developed these ideas with a more explicit global focus, which subsequently appeared in the symposium proceedings (Maguire, 1990). Some of the themes noted then -- cultural change, consumer choice and cultural hegemony -continue to operate as known dimensions of global sport research. More broadly: what do we now know about global sport?

\section{Tracing the diffusion of sport: the current state of play}

The diffusion of modern sport -- its standardization and organizational development -was connected to the formal and informal spheres of influence of the British and other European empires in the late nineteenth and early twentieth centuries. The British settled their empire with the Bible in one hand and a ball and bat in the other - be that in Africa, Australasia, India or those outposts of imperial rule in Asia, Singapore and Hong Kong. Sport forms such as cricket, the different codes of football, lawn tennis and track and field, and Physical Education, with the notion that sport serves some moral purpose, spread across the globe and found expression in the development and diffusion of the modern Olympic movement. De Coubertin was as much influenced by the British as the ancient Greeks.

Likewise, the diffusion of association football to South America stemmed from the actions of British entrepreneurs, diplomatic staff and their naval forces.

Yet, Pax Britannica/Europa gave way to Pax Americana. In the twentieth century, the Americans' sports of football, basketball and baseball diffused, alongside their music, fast food and consumer culture. Even more crucially, the meaning and organization of sport changed. No longer the province of the amateur gentleman, global sport was increasingly 
professional, commodified, and driven by consumption. How then, in the early twenty-first century are we to make sense of the development and contemporary character of global sport?

On the one hand, reinforcing the views of the sports/medical-industrial complex (SMIC) -- a complex interweaving of interests between the state, sport organizations, mediasport and sports goods industries and the sport science/medical professions -- this process has been viewed as a thoroughly progressive and liberating phenomenon that opened up the potential for greater human contact, dialogue and friendship. Advocates argue that sport is a form of global village. Such sentiments find expression in IOC discourse and UN initiatives that employ sport to address a range of development goals.

On the other hand, scholars publishing in IRSS and other sociology of sport journals have shown how the structure of global sport is symptomatic of a new, consumer-dominated phase of Western capitalism. The spread of Western power and its civilization - of which modern sport was a part - led to the destruction of not only habitats but also ludic diversity (play, dance and musical forms). The West dominates economic, technological, political and knowledge resources, and controls the levers of power of global sport. The global SMIC is tied to the opening up of new markets and the commodification of cultures; the consumption of sport is a hallmark of late capitalism. Viewed in this light, and given the actions of the SMIC, contemporary sport represents a form of global pillage - of human resources, habitats, cultures and ludic diversity. Fifty years of research demonstrates that through the SMIC-led production and consumption of global sport products, a narrow selection of Western sport cultures gains ascendancy. Through learning specific embodied techniques in kindergarten, gymnasium, school and club settings, humans develop a body culture that becomes 'second nature', their habitus. Like a language, expressed through these body techniques, humans 
adhere to increasingly standardized forms of expression: the global idiom of achievement sport (Maguire, 2012).

\section{Challenges to the West and to Western Scholars of Sport and Globalization}

Male members of Western societies have long acted as an established group on a world level; their tastes and conduct, including their sports, operate as signs of distinction, prestige and power. But, this is not the whole story. In the establishment of Western zones of prestige, there is evidence for both emulation of, and resistance to, achievement sport. New varieties of body culture emerged, and aspects of ludic diversity survived and, to a degree, globalized. Furthermore, Western culture had long been permeated by non-Western cultural forms, people, technologies, and knowledge: the consumption of non-indigenous cultural wares by different national groups is both active and heterogeneous. Resistance to global sportization processes has also been evident. While cricket was undoubtedly the imperial game, post-colonial peoples in India, Pakistan, Sri Lanka and the islands of the West Indies have since beaten their former colonial masters at their own game. Within Europe, communities in Ireland used traditional games to maintain their identity, language and musical forms and forged a resistance movement that culminated in the formation of the Irish Free State in 1922.

More recently, scholars have explored challenges to the Western dominance of sport . The Soviet bloc's sustained challenge to the West nevertheless incorporated the ideology of achievement sport. Despite ideological differences, Cubans participated in the Olympics, and, by some measures, outperformed the core capitalist countries. Chinese success in the Olympics accelerated with hosting the 2008 Olympic Games in Beijing, and continued at the 2012 London Games. Non-Western success in specific sports such as badminton and middleand long-distance athletics is beginning to be matched by the involvement of non-Western coaches, officials, administrators, producers of sports goods and media outlets, and hosts of 
major tournaments. International teams in table tennis are effectively a national Chinese competition. At the London Olympics thirteen Chinese-born players out of sixty played in the men’s singles; twenty-three of the forty-eight women's singles players were Chinese-born . Note, also, that BRIC nations (Brazil, Russia, India and China ) have been or will be hosts of men’s FIFA World Cup (WC) and the summer or winter Olympic Games; South Africa hosted the men’s FIFA WC, and Qatar was controversially awarded it for 2022. South African citizens did not benefit in economic terms, but politicians and branding firms have been astute in using the FIFA WC for foreign policy and nation branding purposes. In addition, the balance of power in sports such as cricket and badminton appears to be tilting away from the West towards the Indian sub-continent and Asia more generally.

However, the 2014 men’s FIFA WC and the hosting of the 2016 Rio Olympic Games are proving to be mixed blessings for the Brazilian government. Street protests demanding world-class schools and hospitals, and not just the 'bread and circuses' of the sport stadia, highlight that bidding for and hosting mega-events can have unintended consequences: unknown unknowns. While Vladimir Putin was keen to showcase Russia via hosting the 2014 Sochi Olympic Games, this proved embarrassing with regard to the role of oligarchs, the impact on the environment, the lack of consultation with local people, and the broader question of gay/lesbian rights. These examples may indicate a change in the balance of power within global sport; they also highlight both the need to question the use of power and probe issues of democracy, transparency and accountability in the SMIC, and the role that nonEnglish language and non-Western scholars play in exploring the dynamics of sport and globalization.

\section{Future Directions}

What areas of research do we need to know more about? First, an investigation of the continuities and changes involved in the make-up of the SMIC - the global sport power elite - 
is required. Is there evidence for a move away from domination by elite male, able-bodied westerners, and if change has occurred, is there continuity in terms of the influence of alliances between states and between state representatives and the executives of transnational corporations? Second, if sport acts as a 'global idiom' how does this process occur and how is it understood in different cultures and civilizations? Whose tastes shape the global idiom? How this process has played out in different societies, along class, gender and ethnic lines, is yet to be fully understood. Third, the rise of the West was contested and its 'triumph' not inevitable. Cultural interchanges stretch back to long before the West achieved relative dominance in global cultural interchange, and will continue to characterize the future. Yet, we know relatively little about these processes from a non-Western perspective, and the implications for global sport of a potential Pax Sinica remain known unknowns.

Fourth, by focusing on globalization and sport, scholars have often overlooked issues of anti-globalization, and resistance to Western influence, culture and sport. Issues concerning the impact of sport and/on development, the role and impact of mega-events and the exploitative practices of the SMIC, and alternative approaches to the global sport status quo require greater attention both from those within the 'established' groups of nations and those viewed as 'outsiders'. Fifth, linking questions of sport, globalization and body culture to environmentalism could help in examining the wider issues of indigenization, and disappearing worlds. Research could probe the depletion of habitat and also of habitus - of place, space and ludic diversity. Considered in this way the interconnections between globalization and body culture could aid in a new phase in the long-term development of knowledge that has found expression in IRSS over the past fifty years. 


\section{References}

Elias N (1986) Introduction. In: Elias N and Dunning E Quest for Excitement: Sport and Leisure in the Civilizing Process. Oxford: Blackwell, pp.19-62.

Heinilä K (1982) The Totalization Process in International Sport. Jyväskylä: University of Jyväskylä Press.

Maguire J (1988) The commercialization of English elite basketball: 1972-1988.

International Review for the Sociology of Sport 23(4): 305-323.

Maguire J (1990) The Americanization of European sports culture: issues in contemporary cultural change, consumer choice or cultural hegemony. In Tenenbaum, G. \& Eiger, D (eds) Proceedings of the International Symposium for the Sociology of Sport. Israel: (ICSS) Emmanuel Gill, pp. 73-83.

Maguire J (2012) Europeans Body Cultures and the Making of the Modern World: Zones of Prestige and Established-Outsider Relations. Human Figurations 1(1): 1-16.

Taleb N (2007) The Black Swan: The Impact of the Highly Improbable. London: Allen Lane. 